\title{
中下位頸椎損傷に対する観血的治療成績
}

$\begin{array}{cllllll}\text { 鹿児島大学整形外科 } & & & & \\ \text { 内 } & \text { 野 } & & \text { 潔・酒 } & \text { 匂 } & & \text { 崇 } \\ \text { 吉 } & \text { 国 } & \text { 長 } & \text { 利・米 } & & \text { 和 } & \text { 徳 } \\ \text { 伊 } & \text { 藤 } & \text { 博 } & \text { 史・松 } & \text { 永 } & \text { 俊 } & \text { 二 } \\ \text { 岩 } & \text { 崎 } & \text { 正 } & \text { 史・岸 } & \text { 本 } & & \text { 浩 } \\ \text { 橋 } & \text { 口 } & \text { 兼 } & \text { 久 } & & & \end{array}$

\section{Acute Lower Cervical Spine Injury and Spinal Cord Injury : Outcome of Surgical and Nonsurgical Management}

by

Kiyoshi Uchino, Takashi Sakou, Nagatoshi Yoshikuni, Kazunori Yone, Hiroshi Itou, Shunji Matunaga, Masashi Iwasaki, Hiroshi Kishimoto and Masanao Hashiguchi

Department of Orthopedic Surgery, Kagoshima University School of Medicine

Data was collected retrospectively on 72 patients with lower cervical spine injury treated in our Institues. Fifty two patients were treated surgically and twenty treated nonsurgically. At final follow-up no significant difference in neurological recovery was noted between patients treated surgically and those treated nonsurgically. We concluded that the timing of the operation was not effective and that the type of spinal cord injury was the most important prognoshe factor in tems of neurological recovery.

\section{はじめに}

中下位頸椎頸髄損傷に対する治療は観血的治療と保 存的治療に大別されるが，損傷の程度および部位によ る治療方法の選択や，観血的治療を行う際の手術の時 期などについて明確な指針はなく，治療の選択に難渋 することが多い.

そこで，今回我々は，これらの点を明確にすべく， 観血的治療の成績および手術の時期に関して，非手術 例と対比し検討した。

\section{対象および方法}

昭和 57 年以降, 当科㧍よび関連病院で治療を受けた 中下位頸椎頸䯣損傷 72 例を対象とした。性別は男性
60 例, 女性 12 例で, 受傷時年齢は 10 歳 81 歳, 平均 41 歳である. 72 例中手術を施行されたものは 52 例 (72 \%)で，保存的治療を行ったものは 20 例 (38\%) であ る. 72 例中明らかな脊髄損傷を合併していたものは 56 例 $(78 \%$ ) で，そのうち完全麻痺は 17 例, 不完全麻痺 が 39 例であった。その他に神経根症を認めたものが 3 例で, 残り 13 例は特に神経学的異常は認めなかった。 これらの症例につき, 手術群と非手術群に分け, 麻 痺の改善について調査し, 手術群については手術の時 期と麻痺の改善との関係を検討した。 また, 脊髄不完 全麻痺群について, 脊䯣損傷の型と予後についても調 査した. 麻㾇の程度は Frankel の分類に従い 5 段階で 評価した。 


\section{結果}

入院時 Frankel 分類で $\mathrm{A}$ と評価されたもので改善 したものはなく，また手術により麻痺が悪化したもの もなかった。従って, 以下春髄不全損傷 (FrankelB 〜D) 39 例について述べる.

(1) 手術群と非手術群の麻痺の改善について

不完全麻㾝 39 例中手術が行われたものは 29 例で, 保存的治療を行ったものは 10 例であった.

手術群 29 例中麻痺の改善をみたもの 11 例 (38\%) であり, 非手術例では 10 例中 3 例 (30\%) 亿麻痺の改 善を認めた。手術群の改善率が比較的よかったが, 有 意差は認めなかった（図 1$)$.

(2) 手術の時期について

不完全麻痺例のうち手術が行われた 29 例について 受傷日から手術を受けるまでの期間で，2 日以内に行 われたもの，3 日〜 14 日，14 日〜 30日，31 日以上の 4 群に分類し検討した。改善率は各々 $33 \%, 33 \%, 50$ \%, $33 \%$ \%゙あり,これらの 4 群間に有意差は認めなか つた（表 1).

(3)脊髄損傷の型と予後について

不完全麻㽻 39 例の脊髄損傷の型は, 前部損傷が 19 例, 中心性損傷 17 例, Brown-Sequard 型 (B-S 型) が 3 例あった。

前部損傷 19 例中改善したものは 2 例であったのに 対し, 中心性損傷では 16 例中 10 例（1例は術後脳梗
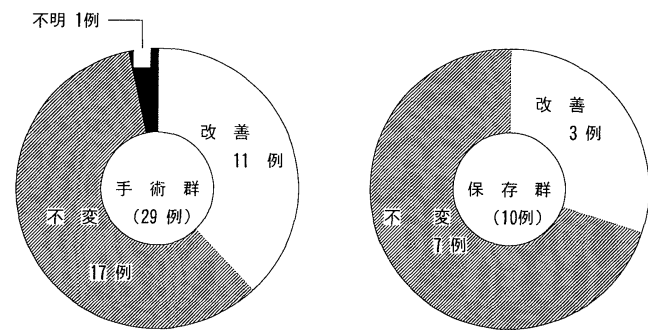

図 1 手術と保存の比較（Frankel 分類 B D )

表 1 改善率（麻瘦例のみ） Frankel $\mathrm{B} \sim \mathrm{D}(\mathrm{N}=28)$ 手術時期 改 善 率

\begin{tabular}{c|l}
\hline $0 \sim 2$ 日 & $33 \%(1 / 3)$ \\
$3 \sim 14$ 日 & $33 \%(4 / 12)$ \\
15〜30日 & $50 \%(2 / 4)$ \\
31 日〜 & $33 \%(3 / 9)$
\end{tabular}

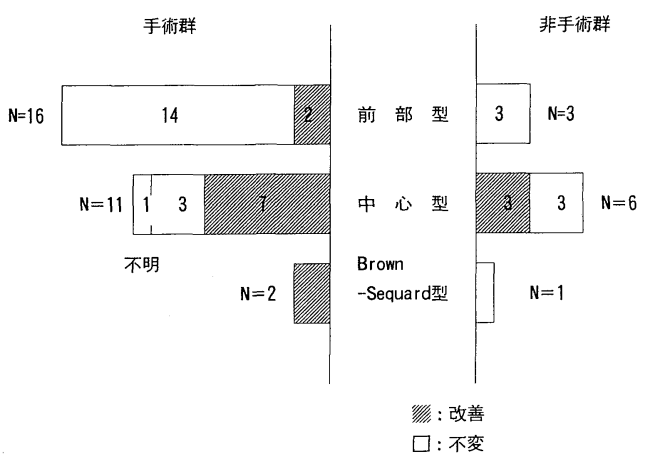

図2＼cjkstart頸髄損傷の型と予後（Frankel B〜D)

塞を起こし判定不能のため除外), $\mathrm{B}-\mathrm{S}$ 型では 3 例中 2 例が改善した。

前部損傷例では麻痺の改善が得られたものが中心性 損傷，B-S 型損傷に比し，有意に少なかった(図 2 ).

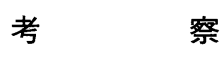

頸椎頸髄損傷に対する観血的治療は, 早期手術を推 奨するもの, 保存的治療を推奨するもの 233) ど意見の 一致をみていない．また，観血的治療においても早期 手術を推奨するもの ${ }^{4) 5}$ や，早期手術の危険性を述べる ものはなどがある。我々は, 頸椎頸髄損傷に対しては早 期離床および早期りハビリテーションを行う目的で不 安定椎に対しては，積極的に手術を行ってきた．今回 これらの症例について, 頸髄損傷に及活寸観血的治療 の効果について検討した。午の結果，手術群と非手術 群間では, 麻痺の改善に関しては, 有意差を認めなか つた。手術群において, 手術の時期と麻痺の改善をみ ると，受傷後 2 日以内に手術を行ったもの，2 週間以 内に行ったもの，1 カ月以内に行ったもの，1 カ月以 上経過してから行ったものの間にも有意差は認めなか つた，脊髄麻痺の予後については，脊䯣損傷の型によ って異なり, 完全麻痺例では, 改善したものは 1 例も なく，中心性損傷や Brown-Sequard 型が前部損傷に 比し予後は良好であった。また，改善の程度は, Fran$\mathrm{kel}$ 分類で 2 段階改善したものは改善例 14 例中 2 例 にすぎず，他はすべて 1 段階の改善であった。

以上の結果より，頸髄損傷に対する観血的治療は， 麻痺の予後に関しては大きな影響を与えないと考えら れ，従って早期手術の意義は少ないと考えられた。 


\section{ま と め}

1.中下位頸椎損傷 72 例の麻痺の改善よりみた治療 成績について検討した。

2. 手術時と非手術群の間で麻痺の改善に有意差は なかった。

3. 手術の時期と麻痺の改善に有意差はなかった。

4. 頸髄損傷の予後には, 春髄損傷の型が最も影響 すると考えられた。

\section{参 考 文 献}

1) Breakman, R., Penning, L,. : Injuries of the cervical spine. Excerpa Medica, Amsterdam, pp. 262, 1971.

2) Dall, D. M. : Injury of the cervical spine. I, Does the type of the bony injuriy affect spinal cord recovery? S. Afr. J., 46 : 1048-1056, 1972.

3) Guttman, S. L. : Spinal cord injuries comp rehen- sive management and research. Black well Scientific Publications, pp. 89-174, 1973.

4) Harris, P.: Some neurosurgical aspects of traumatic paraplegia, Spinal injuries, Harris, P., Morrison and Gibb, Edinburgh pp. 101-112, 1965.

5) Perret, G., Green, J. : Anterior interbody fusion in the treatment of cervical fracture dislocations. Arch, Surg., 96 : 530-5369, 1968.

解 答 鹿児島大学整形外科 内野 潔 1 ) 今後の治療の方針としては, (1)不安定椎の後遺, (2)遅発性麻痺の危険性, (3)早期離床, 早期リハビリ, (4)神経根導傷に対する除圧という観点から, 不安定 型頸椎損傷には, 積極的に手術を行うつもりである. 2 ) 手術例と保存例では対象症例が異なるすのではと いう質問に関して, 頸椎損傷の形態は異なるが, 頸 髄損傷の型には差はないと考える.しかし, 保存例 の症例が少ないため結論は下せない. 